\title{
The Overview of Low Birth Weight Infants with Incidence of Neonatal Jaundice in Perinatology Ward at Dustira Hospital
}

\author{
Yoke Ayukarningsih ${ }^{1,2}$ \\ ${ }^{1}$ Faculty of Medicine, ${ }^{2}$ Departement of Pediatrics \\ ${ }^{1}$ Jendral Achmad Yani University, ${ }^{2}$ RS TK II Dustira \\ Cimahi, Indonesia \\ Siska Telly Pratiwi* \\ Department of Microbiology, Faculty of Medicine \\ Jendral Achmad Yani University \\ Cimahi, Indonesia \\ *siska.telly2@gmail.com
}

\author{
Wahyudin \\ Faculty of Medicine \\ Jendral Achmad Yani University \\ Cimahi, Indonesia
}

\author{
Nadhilah Lailani \\ Faculty of Medicine \\ Andalas University \\ Padang, Indonesia
}

\begin{abstract}
Low Birth Weight (LBW) is an indicator of public health. The morbidity and mortality risk of LBW is 4 times greater than non-LBW. Low birth weight (LBW) both in pre term and term gestational age infants often occurs jaundice. This study aims to determine the distribution of $\mathbf{L B W}$ with neonatal jaundice based on gestational age in Perinatology Ward at Dustira Hospital. This quantitative descriptive study uses data sources from medical records in the Perinatology Ward from January to December 2019. The results of this study showed there were $51(87.9 \%)$ pre-term LBW and $7(12,1 \%)$ term LBW and none post-term LBW infant. There are $42(72,8 \%)$ cases of LBW with neonatal jaundice with $35(83,3 \%)$ pre-term LBW and $7(16,7 \%)$ term LBW. Neonatal jaundice occurrs more often in pre-term LBW than term LBW as done by other studies. The incidence of LBW with neonatal jaundice is not only affected by gestational age, but also by $\mathrm{ABO}$ blood group incompatibility, maternal age during pregnancy, the gender of the infants, and asphyxia.
\end{abstract}

Keywords—low birth weight, gestation age, neonatal jaundice

\section{INTRODUCTION}

Low Birth Weight infants (LBW) is infants with birth weight less than 2500 grams. Gestational age is the common term used during pregnancy to describe the duration of pregnancy, divided into pre-term, term, and post-term. LBW infants in pre-term, term, or post-term gestational age is likely to have health, growth or development problems. This may increase the risk of morbidity, disability, and mortality [1-4].

The morbidity and mortality of LBW infants is 4 times greater than non-LBW, requiring extra care $[4,5]$. LBW infants with pre-term gestational age, mostly has neurology system immaturity and incompatibility of motor and autonomic function. Therefore, the lower of infants' birth weight, greater medical problems it will encounter [6-9].

The prevalence of LBW in Latin America in 2014 was 9\%. The countries with high number of low birth weight infants include Brazil, India, and Nigeria [8,9]. The prevalence of LBW across Indonesia varies, according to RISKESDAS data, LBW infants rate remains high with the percentage $5,4 \%$ in $2007 ; 5,8 \%$ in $2010 ; 5,7 \%$ in 2013 ; and $6,2 \%$ in 2018 . Based on data of West Java Public Health Office, the number of LBW infants was $10,2 \%$ in 2016 and $63 \%$ in 2018 [10-13].

LBW both in pre-term and term gestational age infants often occurs jaundice $[14,15]$. This statement is supported by prior studies by Watchko, et al. [16] and Nurani et al. [9]. According to these studies, there was an association between LBW in pre-term infants and the incidence of neonatal jaundice $[9,16]$. As well, other study done by Rafie R., et al. [11] in the Perinatology Ward at Karawang Regional Hospital, West Java, found $73(42 \%)$ of LBW did not develop hyperbilirubinemia and $101(58 \%)$ developed hyperbilirubinemia from 366 samples. In addition, in this study it was stated that neonates with low birth weight (LBW) had a 1,705 times greater risk of experiencing neonatal jaundice compared to babies born without low birth weight (CI 95\%) [11].

Neonatal jaundice is yellowish discoloration of the skin, mouth cavity, and the sclera due to elevated serum or plasma bilirubin of newborns. Neonatal jaundice either physiological or pathological in newborns can be life threatening. Bilirubin is the final form of heme catabolism. Heme is a degradation product of erythrocyte and other heme proteins including 
myoglobin, cytochrome, catalase, and peroxide [2]. The conditions of increased bilirubin if not treated properly and continues to increase in the blood (hyperbilirubinemia) can cause encephalopathy to kernicterus $[16,17]$.

Dustira Hospital is a Type B Referral Hospital located in Cimahi, West Java. In 2018, the case of LBW was 495 infants from total births. However, study about an overview of LBW infants with the incidence of neonatal jaundice in Dustira Hospital has never been conducted. According to the data above, the researcher was interested in analyzing the overview of LBW with incidence of neonatal jaundice in Perinatology Ward at Dustira Hospital in 2019.

\section{MATERIALS AND METHODS}

This study used descriptive method with a quantitative approach. The sample was taken by using purposive sampling method. Samples data for this study were obtained from medical records with the permission of the Dustira Hospital Ethics Board. The total number of samples was 58 medical records of LBW infants who born from January to December 2019 at Dustira Hospital.

This study consisted of three variables, such as LBW, gestational age, and neonatal jaundice. The instrument of this study was LBW medical records which included infant weight, total bilirubin, and gestational age. In this study, the data were analyzed and then obtained an overview of LBW with physiological or pathological neonatal jaundice based on gestational age and shown as a percentage.

\section{RESULTS AND DISCUSSION}

TABLE I. The INCIDENCE of LBW BASED on GeSTAtionAl AgE

\begin{tabular}{|l|l|l|l|}
\hline \multirow{4}{*}{ LBW } & Gestational age & \multicolumn{1}{|c|}{ n } & \% \\
\cline { 2 - 4 } & Pre-term & 51 & 87,9 \\
\cline { 2 - 4 } & Term & 7 & 12,1 \\
\cline { 2 - 4 } & Post-term & 0 & 0,0 \\
\hline \multicolumn{2}{|l}{ Total } & 58 & 100,0 \\
\hline
\end{tabular}

Based on birth weight, out of total 58 samples, there were 4 $(6,9 \%)$ infants born with a birth weight less than 1499 grams and $54(93,1 \%)$ infants were born with a birth weight between 1500 to 2499 grams. According to gestational age, this study found that $51(87,9 \%) \mathrm{LBW}$ infants were pre-term, $7(12,1 \%)$ infants were a term, and post-term gestational age data were not available. This data is illustrated in Table 1 above.

The finding of this study were consistent with previous study conducted by Mahayasa in 2015, that found there were $129(89,6 \%)$ infants born with a birth weight less than 2500 grams. According to that study, the incidence of LBW was affected by gestational age, teenage pregnancy, sexually transmitted disease and other infection during pregnancy, vegetarian, Intrauterine Growth Restriction (IUGR), multiple pregnancy, hypertension, illegal drugs and alcohol consumption during pregnancy, placenta previa, abnormality of uterus, improper diet, etc. [18]
Infants with pre-term gestational age effects the incidence of LBW [19]. Gestational age affects the maturation of organs, the effectiveness of nutrients distribution, and placental oxygenation required for optimal growth in fetus. In pre-term gestational age, the maturation of organs is not yet completed, accompanied by a lack of efficiency in nutrition and oxygenation of the placenta, which causes the fetal growth not optimal, resulting LBW infants $[3,4]$.

TABLE II. THE INCIDENCE OF NEONATAL JAUNDICE

\begin{tabular}{|l|l|l|}
\hline \multicolumn{1}{|c|}{ Neonatal Jaundice } & \multicolumn{1}{c|}{ \% } & \multicolumn{1}{c|}{ \% } \\
\hline Jaundice & 42 & 72,8 \\
\hline Non Jaundice & 16 & 27,2 \\
\hline Total & 58 & 100,0 \\
\hline
\end{tabular}

TABLE III. THE INCIDENCE OF NEONATAL JAUNDICE BASED BY CLASSIFICATION

\begin{tabular}{|l|l|l|}
\hline \multicolumn{1}{|c|}{ Neonatal Jaundice } & \multicolumn{1}{|c|}{ n } & \multicolumn{1}{c|}{$\%$} \\
\hline Pathologic Jaundice & 24 & 57,1 \\
\hline Physiologic Jaundice & 18 & 42,9 \\
\hline Total & 42 & 100,0 \\
\hline
\end{tabular}

Tables 2 and 3 show that of 58 samples, $42(72,8 \%)$ LBW had neonatal jaundice and $16(27,2 \%)$ LBW had no neonatal jaundice. From 42 LBW infants with neonatal jaundice, 24 $(57,1 \%)$ had physiological jaundice and 18 (42,9\%) had pathological jaundice. The result of this study were consistent with previous study conducted by Olusanya, et al in 2015 and Devi, et al in 2017, discovered that both physiologic and pathologic neonatal jaundice can occur in infants with LBW $[20,21]$.

Neonatal jaundice is yellowish discoloration of the skin, mouth cavity, and the sclera caused by the accumulation of unconjungated bilirubin in newborns, this happens because there is an elevation of the bilirubin plasma needed according to the age of the baby. Neonatal jaundice can occur physiologically or pathologically [4,22].

Neonatal jaundice can occur in LBW either pre-term or term gestational age [17,23]. This occurs because the liver function is not optimal, there is a protein deficiency that plays a role in the transport of neonatal bilirubin, namely albumin and $\mathrm{Y}$ protein or ligandin, causing deposition of bilirubin in blood. Immaturity of the liver in bilirubin metabolism, lack of $\mathrm{Y}$ and $\mathrm{Z}$ proteins, as well as glucoronyl transferase enzyme can cause neonatal jaundice $[22,24]$

TABLE IV. THE INCIDENCE OF LBW WITH NEONATAL JAUNDICE BASED ON GESTATIONAL AGE

\begin{tabular}{|l|l|l|c|}
\hline & Gestational Age & Neonatal Jaundice & \% \\
\hline \multirow{2}{*}{ LBW } & Pre-term & 35 & 83,3 \\
\cline { 2 - 4 } & Term & 7 & 16,7 \\
\hline Total & 42 & 100,0 \\
\hline
\end{tabular}

Table 4 shows, from 42 LBW infants with neonatal jaundice, $35(83,3 \%)$ were in pre-term and $7(16,7 \%)$ were in term gestational age. This finding was consistent with previous 
study by Nurani, et al in 2017, found a significant association between LBW and pre-tem infants with the incidence of neonatal jaundice $[9,16]$. The other study conducted by Saputra in 2016, found that the risk of neonatal jaundice in LBW infants with pre-term gestational age was 6,88 times greater than LBW infants with term gestational age [25]. However, the results were not consistent with the study done by Scafford, et al (2013), which stated that LBW did not affect the incidence of neonatal jaundice [26].

\section{CONCLUSION}

According to the study, the following conclusions were obtaining: there were $51(87,9 \%) \mathrm{LBW}$ infants with pre-term gestational age, $7(12,1 \%) \mathrm{LBW}$ infants with a term gestational age, and post-term gestational age data were unavailable. There were $42(72,8 \%)$ samples of LBW with neonatal jaundice and $16(27,8 \%)$ samples of LBW without neonatal jaundice. Among 42 LBW infants with neonatal jaundice, $24(57,1 \%)$ had physiological jaundice and $18(42,9 \%)$ had pathological jaundice. From 42 LBW infants with neonatal jaundice, 35 $(83,3 \%)$ were in pre-term and $7(16,7 \%)$ were in term gestational age.

Based on this study, there are many other factors that affect the incidence of neonatal jaundice. So further study is required to identify other factors that influence not only the incidence of neonatal jaundice, but also LBW.

\section{REFERENCES}

[1] WHO, Guidelines on optimal feeding of low birth-weight infants in lowandmiddle-income countries. Switzerland: WHO Press, 2011.

[2] M.S. Damanik, Klasifikasi Bayi Menurut Berat Lahir Dan Masa Gestasi. In: S.M. Kosim, A. Yunanto, R. Dewi, I.G. Sarosa, and A. Usman, Editor: Buku Ajar Neonatologi. Jakarta,. 2014, pp. 11 - 7.

[3] S. Feigelman and M.J. Olsson, Assesment of Fetal Growth and Development and The Newborn. In; M.R. Kliegman, F.B. Stanton, S.W.J. Geme, and F.N. Scor, Editor: Nelson Textbook of Pediatrics. 20th edition. Philadelphi, 2016, pp. 60-5.

[4] B.J. Lauer and N.D. Spector, "Hyperbilirubinemia in The Newborn," Pediatric Rev., vol. 32, no. 8, pp. 341-9, 2011.

[5] H.S. Effendi, Pelayanan Kedaruratan Neonatal. Bandung: Refika Aditama, 2013, p. 6

[6] P. Shah and A. Ohissin, "Literature Review of Low Birth Weight, Including Small for Gestational Age and Preterm Birth, Toronto, Ontario: Department of Pediatricas, Mount Sinai Hospital. 2012,” Jurnal Toronto Publich Health, 2019.

[7] D. Jayant, D.B. Phalke, V.B. Bangal, D. Peeyuusha, and B. Sushen, "Maternal Risk factors for Low Birth Weight Neonates: A HospitalBased Case Control Study in Rural Area of Western Maharashtra, India," National Journal of Community Medicine, vol. 2, no. 3 , pp. 394-8, 2011.

[8] WHO, Born Too Soon; The Global Action Report on Preterm Birth. WHO Press, 2012, pp. 2- 14

[9] N.B. Nurani, A.F. Kadi, and T. Rostini, "Incidence of Neonatal Hyperbilirubinemia based on Their Characteristics at Dr. Hasan Sadikin
General Hospital Bandung Indonesia," Althea Medical Journal, vol. 4 no. 3, pp. 431-4, 2017

[10] S. Ullah, K. Rahman, and M. Hedayati, "Hyperbilirubinemia in Neonates: Types, Causes, Clinical Examinations, Preventive Measures and Treatmen: A Narrative Review Article," Iranian Journal of Public Health, vol. 45, no. 5, pp. 558-68, 2016.

[11] M. Rafie and A. Nopiyanti, "Pengaruh Berat Badan Lahir Rendah Terhadap Ikterus Neonatorum Pada Neonatus Di Ruang Perinatologi RSUD Karawang Provinsi Jawa Barat," Jurnal Ilmu Kedokteran Dan Kesehatan, vol. 4, no. 1, 2017.

[12] Kementerian Kesehatan Republik Indonesia, "Riset Kesehatan Dasar Laporan Nasional 2018," [online]. Retrieved from https://www.k4health.org/sites/default/files/laporanNasionalRiskesdas20 18.pdf.

[13] Dinkes Provinsi Jabar, "Profil Kesehatan Provinsi Jawa Barat tahun 2016," [online]. Retrieved from. http://www.depkes.go.id/resources/download/profil/PROFILKES_PRO VINSI_2016/12_Jabar_2016.pdf. Downloaded on August 2019.

[14] I.C.O. Okwundu, A.C. Okoromah, and S.P. Shah, "Prophylactic Phototherapy For Preventing Jaundice In Pretermor Low Birth Weigh Infants Evidence-Based Child Health: A Cochrane Review Journalevid,' Based Child Health, vol. 8, no. 1, pp. 204-249, 2013.

[15] W. Windariza, Besar Risiko Antara Bayi Berat Badan Lahir Rendah Kurang Bulan Dengan Cukup Bulan Terhadap Ikterus Neonatorumdi Rumah Sakit PKU Muhamadiyah Tegal. Thesis Publication, 2017.

[16] J.F. Watchko and M.J. Maisels, "Jaundice in low birthweight infants: pathobiology andoutcome," 2003, [online]. Retrieved from www.archdischild.com. Downloaded on September 1st , 2019.

[17] R.A. Stark and K.V. Bhutani, Neonatal Hyperbilirubinemia. Dalam Cloherty and Stark's, Penyunting.Manual Of Neonatal Care. 8 th edition, Philadelphia, 2017, pp. 335 - 51

[18] T.N.I. Mahayasa, "Hubungan Bayi Berat Lahir Rendah dengan Kejadian Ikterus Neonatorum di RSUD Karawang," Thesis Publication, 2015.

[19] A. Bener, "Socio-Demographic And Consanguinity Risk Factors Associated With Low Birthweight," J Pak Med Assoc, vol. 63, pp. 598 03, 2013.

[20] B.O. Olusanya, F.B. Osibanjo, and T.M. Slusher, "Risk Factors for Severe Neonatal Hyperbilirubinemia in Low and Middle- Income Countries: A Systematic Review and Meta-Analysis," PloS ONE, vol. 10, no. 2, pp. 4-10, 2015.

[21] H. Pusparani and T.W. Ariguntar, "Gambaran Kadar Bilirubin Pada Ikterus Neonatorum Sebelum Dan Pasca Fototerapi Di Rumah Saki Pertamina Cirebon Periode Januari Agustus 2014," Jurnal Ibnu Sina Biomedika, vol. 1, no. 2, 2017

[22] A. Sukadi, Hyperbilirubinemia. in; S.M. Kosim, A. Yunanto, R. Dewi, I.G. Sarosa, and A. Usman A. Editor; Buku Ajar Neonatologi Perpustakaan Nasional Katalog Dalam Terbitan (KDT). Jakarta. 2014 pp. 147-68.

[23] R. Rohsiswatmo and R. Amandito, "Hiperbilirubinemia pada Neonatus >35 Minggu di Indonesia: Pemeriksaan dan Tatalaksana Terkini," Jurnal Sari Pediatri, vol. 20, no. 2, 2018.

[24] F. Wijaya, and I. Suryawan, "Faktor risiko kejadian hiperbilirubinemia pada neonatus di ruang perinatologi RSUD Wangaya Kota Denpasar," Jurnal Medicina, vol. 50, no. 2, 2019.

[25] E. Sulistijono, "Pengaruh Karakteristik Demografis, Klinis dan Laboratorium pada Neonatus dengan Hiperbilirubinemia," Brawijaya Medicine Journal, vol. 26, no. 4, 2011.

[26] G.R. Saputra. Perbedaan Kejadian Ikterus Neonatorum Antara Bayi Prematur Dan Bayi Cukup Bulan Pada Bayi Dengan Berat Lahir Rendah Di RS PKU Muhammadiyah Surakarta. Thesis. Surakarta: Medical Faculty of Surakarta Muhammadiyah University, 2016 